I feel that there are few practitioners to-day who feel the same pride in being known as "the doctor," as they did before the advent of the National Health Service. The truth of the matter is that we are no longer our own masters. We have meekly accepted the public and the State as our masters, with only the occasional (polite) grumble-to each other. When the recent award was announced there were yelps of glee all round for the crumbs brushed to us. I do not really believe that the delight expressed was entirely due to the fact that a practitioner's skill would in future be assessed at $17 \mathrm{~s}$. for the care of one person for one year. Rather I feel that much of the jubilation was in response to the feeling that at last we had stood our ground, hit back, and won a round.

There is a disease abroad in general practice. Tonics, such as the award, or a new suit of clothes, in the form of a College of General Practice, help for just a while. But these are symptomatic measures, not specific treatment.

It is very much the case of "Physician, heal thyself." You do not need a psychiatrist to tell you why you experience this feeling of malaise or why others have lost their respect for you.

If we have a College of General Practice let us not make the mistake of looking to it to solve all our problems and take all our responsibilities, as so many others look to the State to-day. Nor let it detract our attention from the fundamental cause of the decline of general practice. Service to the public or State is one thing, servility another.-I am, etc.,

London, N.22.

D. Silver.

SiR,-Many of us will have been greatly heartened by the remarks concerning a College of General Practice (June 28, p. 1410). Dr. J. H. Hunt has appealed for funds to help this project. May I suggest that all who are interested contribute $2 \%$ of our back-money payment which we are to receive from the Danckwerts award? Half could be sent within the next three months and the remainder when we get the money from the Ministry.

May I suggest another duty of the college ? We are continually bombarded with advertisements from the drug firms about new. products. The value of these products seems to vary inversely with the amount of advertising the firm indulges in. Could not the proposed college let us have some medical evidence on the value of such new products? In America there is such a body which publishes its findings in the J. Amer. med. Ass. I am sure that official and expert advice on a drug's efficacy would greatly help to reduce unnecessary prescribing of proprietary preparations-especially in view of the modern craze for products compounded of more than one standard drug.

In conclusion may $I$ ask the Steering Committee of the new college not to forget doctors in small towns far from big teaching hospitals. - I am, etc.,

Lincoln.

\section{A. H. Ferguson.}

\section{Sport and Medicine}

SIR,-A British Association of Medicine and Sport has recently been formed. Its aims are to promote the study and investigation of the medical and scientific aspects of sport in all its branches. Membership will be open to medical representatives nominated by all national sporting bodies and to any interested medical men and women with a qualification registrable in the United Kingdom. It is hoped that this association will attract a large membership of doctors. Those who are interested are invited to write for particulars to the Hon. Secretary, British Association of Medicine and Sport, c/o British Olympic Association, 71, St. George's Square, London, S.W.1.-We are, etc.,

London, W.1.

Adolphe AbBrahams, President.

Arthur Porritt, Chairman.

\section{POINTS FROM LETTERS}

Lipoma of the Hypopharynx

Dr. A. D. Morgan (London, S.W.1) writes: Dr. J. B. Penfold's report (June 14, p. 1286) of a large pedunculated lipoma of the hypopharynx causing death by asphyxia is reminiscent of a similar tumour reported by Mr. Holt on March 7, 1854 (Trans. Path. Soc., 5, 123), with a colour plate. The specimen is preserved in the museum at Westminster Medical School. The patient had symptoms for 12 years. Microscopically the tumour was a typical lipoma. A similar but much smaller (symptomless) tumour was encountered during a recent necropsy at this hospital.

\section{Succinic Acid in Reiter's Disease}

Dr. R. Vara López (Burgos, Spain) writes: Reiter's syndrome, characterized by a conjunctivitis, urethritis, and polyarthritis, since very seldom only one articulation is affected, sometimes accompanied by other symptoms such as diarrhoea and cutaneo-mucosal affections, in spite of being uncontrolled by a number of treatments has been treated successfully with A.C.T.H. and cortisone. Following the indications of my colleague Professor Rodriguez Candela, and the cortisone-like properties observed by him of succinic acid, we employed this product in $2 \%$ solution on a patient 44 years old, who in 1935 suffered a Reiter's syndrome which lasted four months and recurred in 1950, the symptoms lasting from December till May, though not diagnosed on either occasion as Reiter's syndrome. In February, 1951, urethritis, conjunctivitis, polyarthritis, balanoposthitis, and febricula reappeared. The administration of four phials of $0.15 \mathrm{~g}$. and four of $0.30 \mathrm{~g}$. of "neosalvarsan" did not modify the clinical picture; on the other hand, the intravenous injection of $10 \mathrm{ml}$. of $2 \%$ solution of succinic acid daily cleared the conjunctivitis on the third day of the treatment, the urethritis on the sixth day, and the polyarthritis on the fifteenth day. After 15 months the cure persists.

\section{Incubation of Chicken-pox}

Dr. Lina PotTer (London, N.1) writes: When I was a medical student there was a case of chicken-pox in the hostel where I was living. My mother was morbidly afraid of infection for my sister. I-was planning to visit her at the end of three weeks, when someone told me that the incubation period might be 23 days-so I allowed 28 days to elapse. In the final week in which I had not visited home my sister developed chicken-pox. It is difficult to efiminate the long arm of coincidence in some of the commoner infections.

\section{Geography of Hunger}

Dr. O. D. Gilmore (Highworth, Wilts) writes: It is distressing to read in the correspondence columns of the Journal such letters as those of Drs. David Pyke and Ruth Dovey advocating the immoral practice of contraception as the cure-all for world problems. The pessimistic proclamations of Malthus have been proved by posterity to have been completely unfounded, as the nauseating nostrums proposed by the Neo-Malthusians are now confounded by the evidence put forward by de Castro in Geography of Hunger, which in the words of that great scientist, Lord Boyd Orr, "gives well authenticated facts to show that there is no physical difficulty in doubling or redoubling the world food supply. If the farmers fail us, the chemist has already shown the way to synthetic food .... a world food plan ... the only means of fulfilling the promise of freedom from want, though welcomed by most governments, was rejected by the U.S.A., the U.K., and the U.S.S.R. . . . The story of the economic domination of the earth, and the exploitation of the people and natural resources of weak nations by Western European nations in the last three hundred years and since the Spanish American War by the United States, here set forth fully documented, is a shock to anyone with preconceived ideas of the glories and virtues of our western civilization. It is a story of a ruthless fight for wealth with little regard for the rights or welfare of "inferior races." " This indictment of the "white people" to whom a correspondent so smugly wishes to "teach" immoral practices abhorrent to the majority of the "backward races" calls for an immediate and searching examination of our individual consciences, for we are responsible for this truly horrifying state of affairs in that we have not urged our Government to implement standard 5 of the Atlantic Charter or standard 5 of the Ten Points of 1940 of the Archbishop of Canterbury and his fellow Christians.

\section{Correction}

Dr. Charles Cugel (Sydney, Australia) writes: Sándor Korányi was not a specialist on traumatic diseases (as stated in the Hungarian News and Information Service announcement, May 3, p. 951. He is the founder of modern kidney pathology. He was the first who introduced the determination of the freezing point of the blood into the clinic. 